\title{
Brook Trout Removal as a Conservation Tool to Restore Eagle Lake Rainbow Trout
}

\author{
Gerard Carmona-Catot* \\ Department of Wildlife, Fish and Conservation Biology, University of California-Davis, 1 Shields Avenue, \\ Davis, California 95616, USA; and Institute of Aquatic Ecology, University of Girona, E-17071 Girona, \\ Catalonia, Spain \\ Peter B. Moyle \\ Department of Wildlife, Fish and Conservation Biology, University of California-Davis, 1 Shields Avenue, \\ Davis, California 95616, USA \\ ENRIC APARICIO \\ Institute of Aquatic Ecology, University of Girona, E-17071 Girona, Catalonia, Spain \\ Patrick K. Crain and Lisa C. Thompson \\ Department of Wildlife, Fish and Conservation Biology, University of California-Davis, 1 Shields Avenue, \\ Davis, California 95616, USA \\ Emili García-Berthou \\ Institute of Aquatic Ecology, University of Girona, E-17071 Girona, Catalonia, Spain
}

\begin{abstract}
Nonnative brook trout Salvelinus fontinalis are abundant in Pine Creek and its main tributary, Bogard Spring Creek, California. These creeks historically provided the most spawning and rearing habitat for endemic Eagle Lake rainbow trout Oncorhynchus mykiss aquilarum. Three-pass electrofishing removal was conducted in 2007-2009 over the entire 2.8-km length of Bogard Spring Creek to determine whether brook trout removal was a feasible restoration tool and to document the life history characteristics of brook trout in a California meadow stream. After the first 2 years of removal, brook trout density and biomass were severely reduced from 15,803 to 1,192 fish/ha and from 277 to $31 \mathrm{~kg} / \mathrm{ha}$, respectively. Average removal efficiency was $92-97 \%$, and most of the remaining fish were removed in the third year. The lack of a decrease in age- 0 brook trout abundance between 2007 and 2008 after the removal of more than 4,000 adults in 2007 suggests compensatory reproduction of mature fish that survived and higher survival of age- 0 fish. However, recruitment was greatly reduced after 2 years of removal and is likely to be even more depressed after the third year of removal assuming that immigration of fish from outside the creek continues to be minimal. Brook trout condition, growth, and fecundity indicated a stunted population at the start of the study, but all three features increased significantly every year, demonstrating compensatory effects. Although highly labor intensive, the use of electrofishing to eradicate brook trout may be feasible in Bogard Spring Creek and similar small streams if removal and monitoring are continued annually and if other control measures (e.g., construction of barriers) are implemented. Our evidence shows that if brook trout control measures continue and if only Eagle Lake rainbow trout are allowed access to the creek, then a self-sustaining population of Eagle Lake rainbow trout can become reestablished.
\end{abstract}

The brook trout Salvelinus fontinalis, a char native to eastern North America (MacCrimmon and Campbell 1969), has been successfully introduced into 31 countries and 38 U.S. states outside of its native range (Helfman 2007). In the late 1800s, brook trout were brought to California and were widely distributed around the state. Across North America, brook trout

\footnotetext{
* Corresponding author: carmona.catot@gmail.com
}

Received April 8, 2010; accepted August 9, 2010 Published online November 1, 2010 have been implicated in the decline of many salmonid species, including Chinook salmon Oncorhynchus tshawytscha (Levin et al. 2002), cutthroat trout $O$. clarkii (Dunham et al. 2002), bull trout S. confluentus (Rieman et al. 2006), and golden trout O. mykiss aguabonita (Moyle 2002). Established populations of nonnative brook trout often exhibit higher densities and production rates than do native salmonids (Benjamin and Baxter 2010).

Brook trout were introduced into Pine Creek, California, in 1940-1949 to provide a stream sport fishery and were soon abundant in the creek and its 
principal tributary, Bogard Spring Creek. These two creeks originally provided the most spawning and rearing habitat for Eagle Lake rainbow trout $O$. mykiss aquilarum. This subspecies is endemic to the Eagle Lake basin and represents the only rainbow trout $O$. mykiss subspecies that is native to the Great Basin. Eagle Lake rainbow trout are stream spawners and originally moved about $45 \mathrm{~km}$ up Pine Creek from Eagle Lake to spawn in response to high spring flows. The principal spawning and rearing areas were perennial reaches of Pine and Bogard Spring creeks. Juveniles presumably spent their first 1-2 years in the stream before moving into the lake during high flow periods in spring, although it is possible that some individuals remained as stream residents (Moyle 2002).

Eagle Lake rainbow trout were on the verge of extinction in the 1950s due to degradation of their spawning streams, reduced access to these streams from Eagle Lake, and overfishing. The last few spawners were rescued for captive rearing by the California Department of Fish and Game (CDFG; Moyle 2002; Moyle et al. 2008), and hatchery production now supports a successful trophy fishery in Eagle Lake. However, the presence of brook trout in spawning streams has discouraged efforts to reestablish natural runs of Eagle Lake rainbow trout, despite numerous actions to improve stream habitats and access for migrating fish (Pustejovsky 2007). Nevertheless, some mature Eagle Lake rainbow trout were transported into headwater areas by CDFG in 2006 and 2007 (P. Divine, CDFG, personal communication). At least some of these fish spawned successfully, as indicated by the presence of juveniles in the creeks ( $\mathrm{P}$. B. Moyle, personal observation). Because of the complete dependence of Eagle Lake rainbow trout on hatchery production, the American Fisheries Society considers it to be a threatened species and NatureServe has listed it as critically imperiled (Jelks et al. 2008). Moyle et al. (2008) consider it to be one of the most endangered salmonids in California. However, a petition for listing the Eagle Lake rainbow trout as a threatened species was rejected by the U.S. Fish and Wildlife Service in 1994, and a similar petition was rejected by the California State Fish and Game Commission in 2004.

In California, problem populations of nonnative fishes historically have been removed with piscicides. A chemical treatment to eradicate brook trout from the Pine Creek watershed has generally not been considered because of the possibility of harming endemic invertebrate species and because of legal and social complications (Moyle et al. 2008). Thus, electrofishing was evaluated as an alternative to poisoning because it has minimal effects on nontarget species.

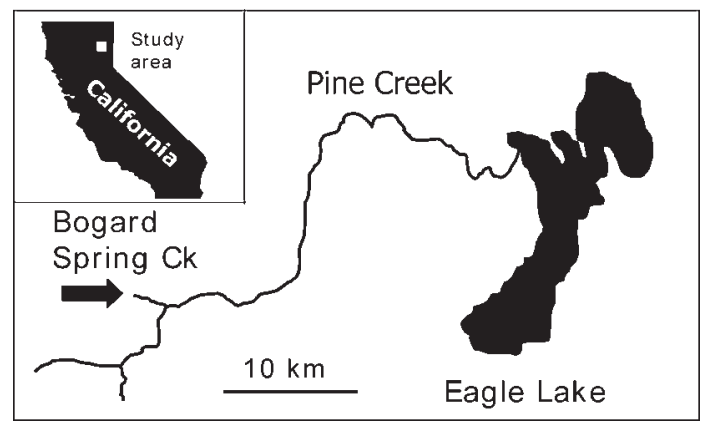

Figure 1.-Location of Bogard Spring Creek in the Eagle Lake basin, California. Inset map shows the location of the study area within the state.

Kulp and Moore (2000) documented that multiple, thorough electrofishing removals over several years depleted or eliminated nonnative rainbow trout from several streams, allowing for recovery of native brook trout in the Great Smoky Mountains National Park in the eastern USA. Electrofishing removal of brook trout for restoration of Colorado River cutthroat trout $O$. clarkii pleuriticus in Wyoming did not eradicate brook trout but significantly reduced their abundance (Thompson and Rahel 1996). However, remaining fish often undergo compensatory responses, which can partly offset the removal of large quantities of the nonnative fish. Thus, removal of the target fish species from a creek is likely to be expensive, labor intensive, and difficult to achieve (Meyer et al. 2006).

The objectives of the present study were to (1) evaluate the effects of 3 years of electrofishing removal used to experimentally depress the brook trout population in Bogard Spring Creek, (2) assess the indirect effects of electrofishing removal on brook trout life history traits, including compensatory effects, and (3) determine whether a brook trout reduction program could benefit Eagle Lake rainbow trout.

\section{Methods}

Study area.-Bogard Spring Creek is situated in northeastern California within the boundaries of Lassen National Forest. The study area includes the entire 2.8 $\mathrm{km}$ of the creek from its headwater spring to its confluence with Pine Creek, the main tributary flowing into Eagle Lake (Figure 1). With a surface area of 8,900 ha, Eagle Lake is the second-largest natural lake entirely contained in California; it is a terminal lake with highly alkaline water (Young 1989). Bogard Spring Creek is a spring-fed creek with average summer flows of $0.015 \mathrm{~m}^{3} / \mathrm{s}$, an average wetted width of $1.2 \mathrm{~m}$, and a depth of $0.1 \mathrm{~m}$ during the summer (Carmona-Catot 2009). The creek descends from 1,775 
to $1,725 \mathrm{~m}$ through low-gradient meadows and slightly steeper forested reaches. The creek has pools and glides with deeply undercut banks and substrates of sand and gravel. The banks are dominated by grasses and sedges with patches of willows Salix spp. and other riparian shrubs, while the surrounding forest lands are covered with mixed conifers Pinus spp. and quaking aspen Populus tremuloides (Pustejovsky 2007). At the initiation of this study, Bogard Spring Creek supported a large brook trout population but only low numbers of juvenile Eagle Lake rainbow trout, Tahoe suckers Catostomus tahoensis, and speckled dace Rhinichthys osculus. These native species are spring spawners, whereas brook trout spawn in the fall.

Electrofishing sampling and brook trout removal.The entire length of Bogard Spring Creek from its confluence with Pine Creek to its source was divided into 30 sections, each approximately $100 \mathrm{~m}$ long. Electrofishing was conducted in each section during August 20-24, 2007; September 8-12, 2008; and September 5-9, 2009. The study took place when creek flows were at their lowest and before brook trout had spawned. Prior to electrofishing, block nets $(0.6-\mathrm{cm}$ mesh) were placed across the creek at the upstream and downstream boundaries of each section. Three-pass depletion electrofishing was conducted using a batterypowered backpack electrofishing unit (Smith-Root Model 12B) with pulsed DC set at $4 \mathrm{~ms}, 500-700 \mathrm{~V}$, and $60 \mathrm{~Hz}$. All brook trout collected were measured (mm fork length [FL]), weighed $(\mathrm{g})$, and euthanized using compression fracture of the skull. Other species were measured, weighed, and released at the same location where captured. At each site, wetted width was recorded at $20-\mathrm{m}$ intervals to calculate the area sampled $\left(\mathrm{m}^{2}\right)$.

It is possible for fish to move from Pine Creek into Bogard Spring Creek during snowmelt flow events. However, for much of the year, Pine Creek flow past the mouth of Bogard Spring Creek is low to nonexistent. To assess fish movement from Pine Creek to Bogard Spring Creek, 900 brook trout, 194 Tahoe suckers, 49 speckled dace, 3 Eagle Lake rainbow trout, and 14 Lahontan redsides Richardsonius egregius were fin-clipped and released into Pine Creek close to the confluence with Bogard Spring Creek during July, September, and October 2008.

Life history analyses.-Scales from sampled brook trout (2007: $n=30 ; 2008: n=30 ; 2009: n=38$ ) were used to develop year-specific age-at-length relationships. Otoliths from some of these brook trout were also examined (2008: $n=25 ; 2009: n=33$ ). The age readings based on scales were in agreement with those obtained from otoliths. The different aging methods disagreed only for a few of the oldest brook trout.
Growth rates were compared among years by calculating the mean FL at age. In 2008 and 2009, gonadal weight was measured (nearest $0.1 \mathrm{mg}$ ) from 158 brook trout, and the number of eggs was counted from a subsample of 44 mature females (Strange 1996). Due to sampling constraints, no otoliths or gonadal tissues were collected in 2007.

Population estimation and removal efficiency.Population sizes from removal-depletion data were estimated using MicroFish version 3.0 (Van Deventer and Platts 1989), which uses Burnham maximum likelihood estimation. Subsequently, brook trout densities (fish/ha) and biomass (kg/ha) were estimated for the different size-groups at each of the 30 sites. Removal efficiency was determined by dividing the total number of brook trout captured by the estimated population size of brook trout. To estimate annual mortality rates for comparison among cohorts and years, abundance of each age-class in a given year was divided by the abundance of the anterior age-class from the previous year. These mortality estimates were also used to evaluate removal efficiency, even though the estimates included both natural mortality and mortality caused by removal. In addition, this methodology assumed constant natural mortality over the years.

Statistical analyses.-Brook trout density and biomass were compared between years by analysis of covariance (ANCOVA) using distance from each site to the mouth of Bogard Spring Creek as a covariate (and year as a factor) because density significantly decreased upstream. The quadratic term of distance to mouth was also used as an additional covariate to account for nonlinear variation in abundance. For a posteriori comparison of adjusted estimates between years, we used "repeated" contrasts, which only compare successive years (García-Berthou and Moreno-Amich 1993). To compare fish condition, fecundity, and other life history traits between years, we also performed ANCOVA with brook trout FL as the covariate. Estimated marginal means of the dependent variable were the means for each level of the factor, adjusted for covariates with ANCOVA, and were used to describe the differences in brook trout condition among years (García-Berthou and Moreno-Amich 1993). Data for FL, total weight, gonadal weight, and number of eggs were $\log _{10}$ transformed for analyses because the linearity and homoscedasticity assumptions were more likely to be satisfied. The nonparametric Kolmogorov-Smirnov (K-S) test was also used to determine whether length-frequency distributions changed over the years. Analyses were performed with the Statistical Package for the Social Sciences version 15 (SPSS, Inc., Chicago, Illinois). 

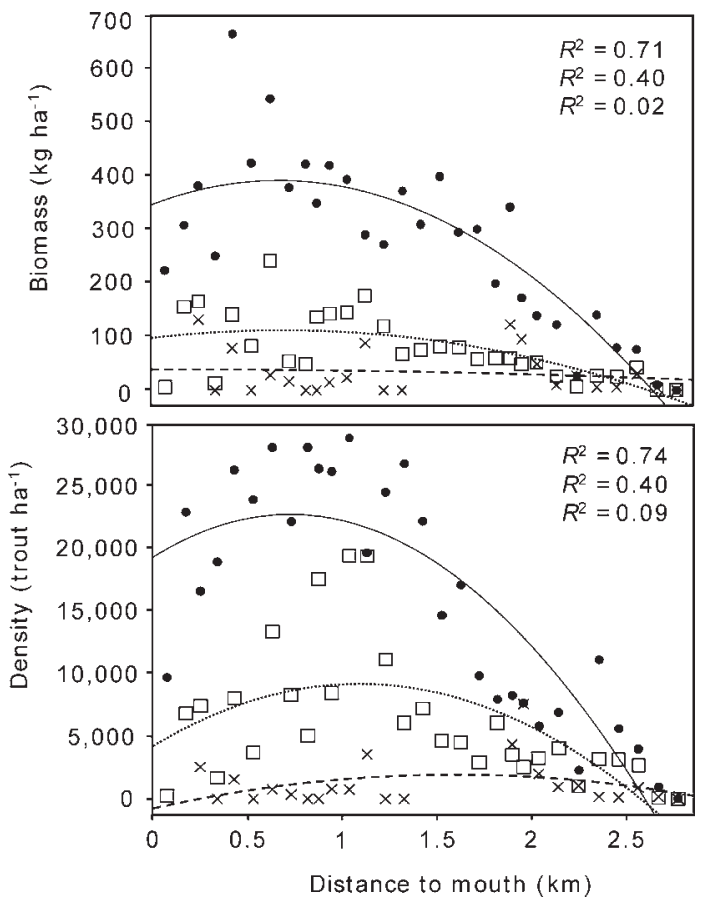

Figure 2.-Estimated brook trout biomass ( $\mathrm{kg} / \mathrm{ha}$ ) and density (fish/ha) in relation to distance from the mouth of Bogard Spring Creek, California, 2007-2009 (black circles = 2007; open squares $=2008 ; \times$ symbols $=2009)$. Quadratic regression lines and $R^{2}$ values are given for the 2007 (solid line; upper $R^{2}$ value), 2008 (dotted line; middle value), and 2009 (dashed line; lower value) models.

\section{Results}

\section{Abundance and Biomass}

During the study, 7,264 fish were captured in Bogard Spring Creek. Of these, 91.5\% were brook trout, $3.7 \%$ were speckled dace, $3.4 \%$ were Eagle Lake rainbow trout, and $1.5 \%$ were Tahoe suckers. The number of brook trout euthanized was 4,887 in 2007,
1,550 in 2008, and 208 in 2009. Brook trout were present throughout the creek in 2007 and 2008 except in the headwater springs during 2008, and brook trout were absent from 9 of the 30 sites in 2009. Eagle Lake rainbow trout juveniles were present mainly at the middle and lower sites; the number of juveniles captured was 169 in 2007, 25 in 2008, and 34 in 2009.

Density and biomass of brook trout were highest in the intermediate reaches of the creek (Figure 2). This distribution pattern became less pronounced over the 3 years of removal. After accounting for this spatial pattern, brook trout density (ANCOVA: $F=16.30$; df $=2,74 ; P<0.001$ ) and biomass (ANCOVA: $F=$ 16.33 ; $\mathrm{df}=2,74 ; P<0.001)$ decreased across years. Only the density of age- 0 brook trout was not significantly different between 2007 and 2008 (repeated contrast: $P=0.74$ ), but it decreased significantly in 2009 (repeated contrast: $P<0.001$; Table 1; Figure 3). Average removal efficiency of three-pass electrofishing was lower for age- 0 brook trout than for older brook trout (Table 1), and total efficiency increased from 2007 to 2009. Annual mortality rates from 2007 to 2008 were 0.62 for the 2007 cohort, 0.82 for the 2006 cohort, and 0.97 for the 2005 cohort. The mortality rates from 2008 to 2009 were 0.92 for the 2008 cohort, 0.89 for the 2007 cohort, and 0.99 for the 2006 cohort.

\section{Population Structure}

The brook trout length-frequency distributions were significantly different between 2007 and 2008 (K-S test: $Z=5.55, P<0.001)$ and between 2008 and 2009 (K-S test: $Z=5.42, P<0.001$ ). In $2007,42 \%$ of the brook trout catch consisted of age-1 fish, followed by age-2 (30\%) and age-0 (19\%) fish. In 2008, age-0 brook trout comprised $50 \%$ of the catch, whereas age- 1 and age- 2 brook trout each accounted for $23 \%$ of the catch. In 2009, $47 \%$ of the brook trout catch was age 1 , $27 \%$ was age 2 , and $22 \%$ was age 0 . The oldest and least abundant brook trout in the stream were age 3 (Figure 3).

TABLE 1.- Total catch, estimated removal efficiency (RE), estimated density, estimated biomass, mean fork length (FL), and FL range of brook trout in Bogard Spring Creek, California, during electrofishing surveys from 2007 to 2009 . Standard deviations are also shown (in parentheses) for density, biomass, and FL.

\begin{tabular}{lccccccc}
\hline Component & Year & Total catch & RE & Density (fish/ha) & Biomass (kg/ha) & Mean FL (mm) & FL range (mm) \\
\hline \multirow{2}{*}{ Total population } & 2007 & 4,887 & 0.92 & $15,803(1,723)$ & $277.2(29.0)$ & $103.0(0.6)$ & $33-300$ \\
& 2008 & 1,550 & 0.96 & $6,193(970)$ & $78.0(11.2)$ & $93.1(0.8)$ & $44-224$ \\
\multirow{4}{*}{ Age 1 and older } & 2009 & 139 & 0.97 & $1,196(382)$ & $31.7(8.7)$ & $127.0(3.1)$ & $62-239$ \\
& 2007 & 4,009 & 0.92 & $12,763(1,356)$ & $270.5(28.4)$ & $119.1(0.6)$ & $78-300$ \\
Age 0 & 2008 & 835 & 0.98 & $3,371(528)$ & $68.6(10.6)$ & $116.6(0.9)$ & $81-224$ \\
& 2009 & 109 & 0.98 & $953(274)$ & $32.1(9.0)$ & $140.7(2.5)$ & $104-239$ \\
& 2007 & 878 & 0.89 & $3,042(469)$ & $4.8(0.7)$ & $59.2(0.3)$ & $33-77$ \\
& 2008 & 715 & 0.93 & $2,850(591)$ & $8.6(1.4)$ & $65.5(0.3)$ & $44-80$ \\
& 2009 & 30 & 0.97 & $243(123)$ & $1.2(0.6)$ & $75.2(1.4)$ & $62-98$ \\
\hline
\end{tabular}




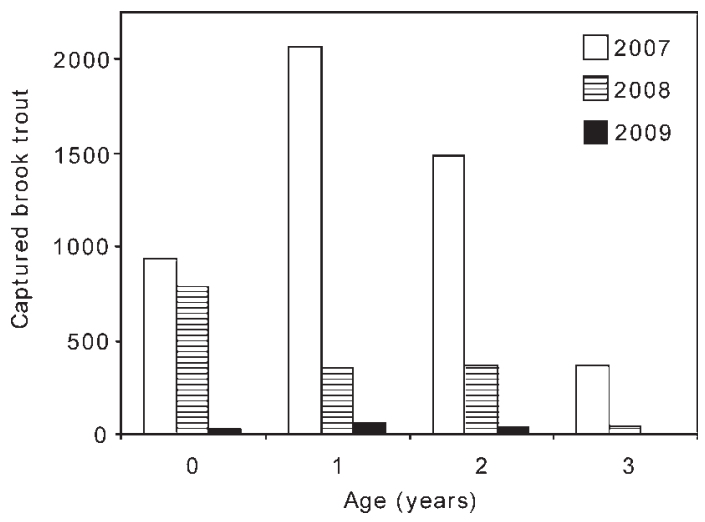

FIGURE 3.-Age distribution of brook trout captures in Bogard Spring Creek, California, from 2007 to 2009.

All Eagle Lake rainbow trout were promptly returned to the creek after capture. Length frequencies for 2007 ( $n=169), 2008(n=25)$, and $2009(n=34)$ indicated that in September (near the presumed end of the growing season), age- 0 Eagle Lake rainbow trout were $60-120 \mathrm{~mm}$ FL, yearlings were $130-170 \mathrm{~mm}$ FL, and 2-year-olds were greater than $180 \mathrm{~mm}$ FL.

\section{Life History Traits}

The largest brook trout captured was $300 \mathrm{~mm}$ FL in 2007, $224 \mathrm{~mm}$ in 2008, and $239 \mathrm{~mm}$ in 2009. The smallest brook trout captured was $33 \mathrm{~mm}$ FL in 2007, $44 \mathrm{~mm}$ in 2008, and $62 \mathrm{~mm}$ in 2009. Between 2007 and 2008, mean FL increased by $15.0 \mathrm{~mm}$ for brook trout at age $0,12.7 \mathrm{~mm}$ for age 1 , and $15.3 \mathrm{~mm}$ for age 2 ; however, there was a $6.6-\mathrm{mm}$ decrease for age- 3 fish. Between 2008 and 2009, mean FL increased by $6.7 \mathrm{~mm}$ for age- 0 brook trout, $23.8 \mathrm{~mm}$ for age- 1 fish, $10.5 \mathrm{~mm}$ for age- 2 fish, and $36.0 \mathrm{~mm}$ for age- 3 fish (Figure 4). Fish condition increased significantly every year (ANCOVA: $F=40.29$, df $=2,5,071, P<0.001$; Figure 5).

We found significant differences in reproductive characteristics between 2008 and 2009 after accounting for fish size. In males, gonadal weight increased significantly between years (ANCOVA, year $\times$ FL: $F=$ 18.68; $\mathrm{df}=2,77 ; P<0.001)$. Similarly, in females, gonadal weight $($ ANCOVA, year $\times$ FL: $F=7.04$; $\mathrm{df}=$ 2, 66; $P<0.01$ ) and ova number (standard ANCOVA: $F=15.09 ; \mathrm{df}=1,41 ; P<0.001)$ also significantly increased between 2008 and 2009 (Figure 6).

Of the 1,160 fish (all species) marked in Pine Creek, only three large mature brook trout $(186,191$, and 239 $\mathrm{mm}$ FL) were recaptured in lower Bogard Spring Creek, less than $0.25 \mathrm{~km}$ from the mouth.

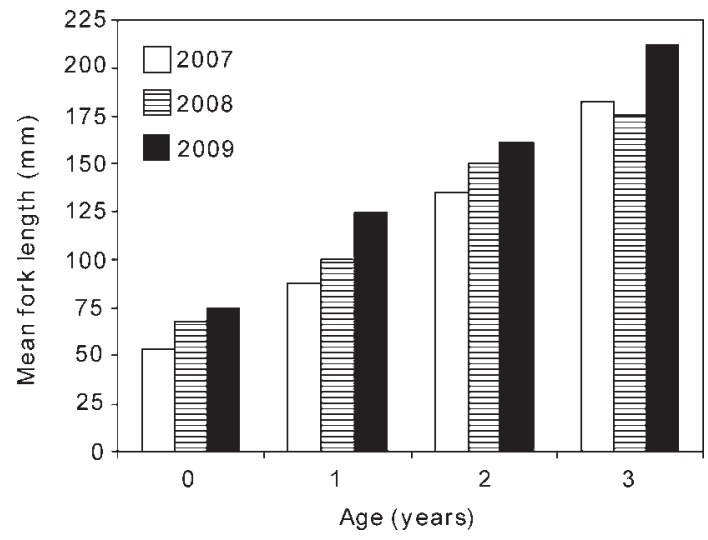

FIGURE 4.-Brook trout mean fork length at age in Bogard Spring Creek, 2007-2009, based on length-age keys for each respective year.

\section{Discussion}

Three years of intensive electrofishing removal severely reduced the brook trout population in Bogard Spring Creek, indicating this method's potential for improving rearing conditions for Eagle Lake rainbow trout. Although there was a severe decline in adult brook trout abundance after 3 years of removal, enough brook trout remained to successfully reproduce even after the population's near-eradication in 2009. The lack of a clear decrease in age- 0 brook trout between 2007 and 2008 after the extirpation of more than 4,000 adult brook trout in 2007 suggests the occurrence of compensatory reproduction from remaining brook trout and increased survival of age- 0 fish. Even though age- 0 brook trout numbers remained similar from 2007 to

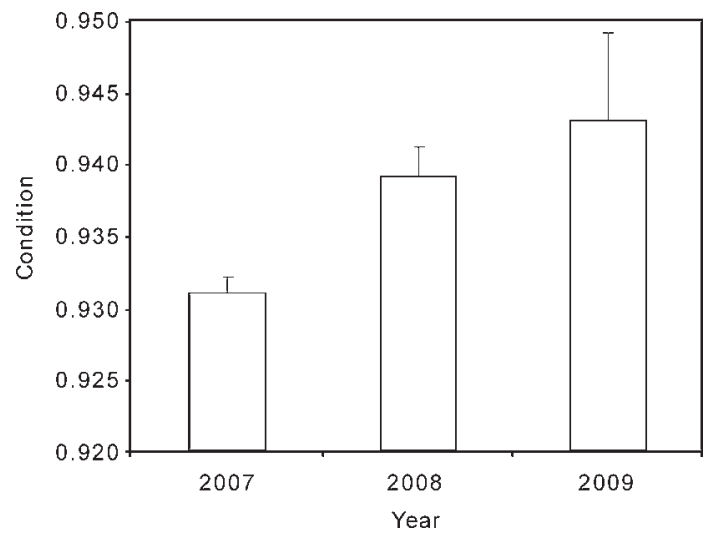

FIGURE 5.- - Individual condition of brook trout in Bogard Spring Creek from 2007 to 2009. Estimated adjusted means ( $+\mathrm{SE}$ ) of weight (adjusted for fork length with analysis of covariance) are shown. Both variables were $\log _{10}$ transformed. 


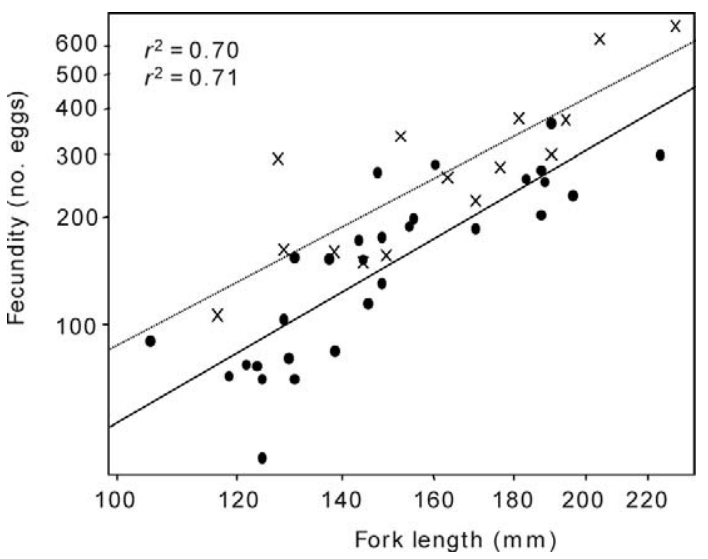

FIGURE 6.-Relationship between fecundity (number of eggs) and fork length of brook trout in Bogard Spring Creek (black circles $=2008 ; \times$ symbols $=2009$ ). The linear regressions and $r^{2}$ values are shown. Note the log scale of both axes.

2008, their average biomass increased from 4.8 to 8.6 $\mathrm{kg} / \mathrm{ha}$. This increase was accompanied by increased individual growth, fecundity, and condition, all of which have negative relationships with density (Donald and Alger 1989; Jenkins et al. 1999). Therefore, annual electrofishing should be maintained to keep brook trout numbers low.

While only three marked adult brook trout from Pine Creek were later recovered in Bogard Spring Creek, their presence indicates that recovery of the population after depletion is likely (Peterson and Fausch 2003; Roghair and Dolloff 2005). The low number is presumably due in part to the relatively dry years of the study period, during which Pine Creek at the mouth of Bogard Spring Creek was dry in summer.

\section{Removal Efficiency}

Bogard Spring Creek supported higher pretreatment brook trout densities in comparison with other streams where similar eradication studies have been conducted (e.g., Thompson and Rahel 1996; Meyer et al. 2006). Our adult brook trout removal efficiencies were similar to those of other projects during the first 2 years but were higher in the third year. First-year removal efficiency of age-0 brook trout was similar between our study and the study by Meyer et al. (2006), but our efficiencies for the second and third years $(93 \%$ and $97 \%$, respectively) were higher than theirs $(29 \%$ and $42 \%)$. Creek size could explain these differences: Meyer et al. (2006) evaluated the removal of brook trout from a stream reach that was longer and $1.6 \mathrm{~m}$ wider than the reaches in our study, and the removal effort in their study was equivalent to two thorough passes in each station. Thus, electrofishing removal is more likely to be successful in small creeks (e.g., Bogard Spring Creek) than in larger systems, where electrofishing capture efficiencies are lower. Underestimation of population size by the depletion-removal method is common, so our removal efficiencies and those of other studies might be inflated because they were calculated as number of fish captured divided by the estimated number (Riley and Fausch 1992; Thompson and Rahel 1996). In addition, due to lower electrofishing efficiency for small fish (Bohlin et al. 1989), age-0 brook trout are difficult to capture. Bogard Spring Creek had deep undercuts, high quantities of large woody debris, and in some areas, overhanging vegetation, which probably further lowered the removal efficiency for small fish (Peterson and Cederholm 1984; Shepard and Nelson 2002). However, as recommended by Kulp and Moore (2000), removals were delayed until late summer to allow age0 brook trout to grow to larger sizes, thus increasing their susceptibility to electrofishing while water temperatures were still warm. We used mortality rates as an alternative method to evaluate electrofishing as a removal technique. Annual mortality rates from 2007 to 2008 were lower than electrofishing efficiency estimates, especially for age-0 fish; however, age-0 mortality rates for 2008 to 2009 were higher than age- 0 electrofishing efficiency. Mortality rate calculations assumed that natural mortality was constant and that most additional mortality was caused by electrofishing. Annual mortality rates for age- 1 and age- 2 brook trout were higher than those for age- 0 fish. Mortality rates for age-0 fish significantly increased by $35 \%$ from 2007 to 2008 . This can be explained in part by a lower abundance of large fish (on which electrofishing personnel naturally tend to focus capture efforts), thereby allowing more attention to be given to smaller fish. Recruitment was greatly reduced after 3 years of removal, and recovery of brook trout populations in Bogard Spring Creek will presumably depend on recolonization from Pine Creek.

For the 3 years of the study, we accumulated 205 person-days for the electrofishing treatment alone (i.e., not including project planning time or preproject meetings). Most person-days came from permanent or temporary employees of the organization involved in the removal, but there were also a number of volunteers. For calculation purposes, we conservatively assumed an average salary (with benefits) based on the California minimum wage in 2009 (US\$8 per hour) plus benefits at $30 \%$, an average working day of $10 \mathrm{~h}$ (no overtime pay), and an average per diem rate of $\$ 44$ (meals and incidental expenses, not including lodging). Travel costs were based on four passengers per vehicle, 
with round-trip travel distance of $96 \mathrm{~km}$ to the nearest large town each day, university fleet rental costs of $\$ 62.56$ per day for each vehicle, and a mileage expense of $\$ 0.17$ per kilometer. We did not include the costs of equipment (e.g., electrofishers) or supplies (e.g., block nets, hand nets, scales, and measuring boards) because these items were already in the inventories of the participating agencies. Based on these assumptions, the total project cost was about $\$ 30,000$ overall $(\$ 10,700$ per creek kilometer) for 3 years or about $\$ 10,000$ per year. This is comparable with costs calculated for earlier studies (Shepard et al. 2002; Meyer et al. 2006).

\section{Implications for Restoration of Eagle Lake Rainbow Trout}

Preremoval (2007) densities of brook trout (average $\approx 16,000 \mathrm{fish} / \mathrm{ha}$, with local densities up to 30,000 fish/ha) were among the highest recorded for California (Carmona-Catot 2009; P.B.M., unpublished data). The small size at age compared with other brook trout populations (e.g., McFadden 1961; McFadden et al. 1967; Meyer et al. 2006) suggests stunting due to intraspecific competition. Curiously, the juvenile Eagle Lake rainbow trout did not seem to exhibit reduced growth in 2007, with age-0 fish averaging $86 \mathrm{~mm}$ FL, which is large for rainbow trout in small California streams (Moyle 2002). This information indicates that the Pine Creek watershed could also be highly productive for Eagle Lake rainbow trout juveniles if brook trout populations can be reduced. During spring 2009, 30 adult Eagle Lake rainbow trout were transported to Bogard Spring Creek, and successful spawning and fry emergence were subsequently observed (Carmona-Catot 2009). Because some successful spawning and rearing previously occurred even at high brook trout densities, we assume that greatly increased growth and survival of juvenile Eagle Lake rainbow trout will occur in areas where brook trout are severely depleted. Although Pine Creek is too large to make electrofishing removal a practical option for its management, creating spawning and rearing refuges in Bogard Spring Creek and in spring systems farther upstream may be sufficient to reestablish at least small populations of naturally reproducing Eagle Lake rainbow trout after an absence of more than 60 years. If the extirpation of natural spawning runs of Eagle Lake rainbow trout was caused primarily by poor habitat conditions (as is likely; Moyle 2002; Pustejovsky 2007), then the current ongoing habitat restoration program combined with selective brook trout control (Peterson et al. 2004) should result in restoration of natural runs of this endemic trout. Rainbow trout can displace brook trout in some situations (e.g., Kulp and Moore 2000), and this may be possible in Pine Creek if
Eagle Lake rainbow trout can be given a substantial population boost.

A challenge for Eagle Lake rainbow trout restoration is probably interspecific competition between the two species during the first months of life because brook trout fry are slightly larger than Eagle Lake rainbow trout fry given their different emergence times. In Bogard Spring Creek, brook trout start to spawn in October and the first age-0 fish are observed in May; Eagle Lake rainbow trout spawn from March to May, and age- 0 fish have been observed as early as June. In July 2009, brook trout fry averaged $50 \mathrm{~mm}$ FL, or 10 $\mathrm{mm}$ longer than Eagle Lake rainbow trout fry (Moyle and Carmona-Catot 2009). Therefore, it is important to reduce the population of mature brook trout in the fall before they spawn and thus decrease the abundance of age-0 brook trout. Shepard et al. (2002) also found size differences between brook trout and westslope cutthroat trout $O$. clarkii lewisi during the first year of life and highlighted the importance of high-quality rearing habitat for restoration of native trout. Curiously, while brook trout are able to displace native trout (e.g., cutthroat trout and rainbow trout) in the western United States, brook trout are themselves displaced by nonnative rainbow trout in their native range in the Southeast. Fausch (2008) suggested that fish from the edges of their native ranges are less well adapted to local environmental conditions and that successful introduced fishes are better adapted by chance to these conditions. Eagle Lake rainbow trout are dependent on high-elevation meadow systems for reproduction, and this habitat is relatively uncommon in the native range of rainbow trout in California (Moyle 2002). Eagle Lake rainbow trout could therefore be less adapted for such conditions than introduced brook trout.

Efforts to reestablish a self-sustaining population of Eagle Lake rainbow trout should continue to focus on Bogard Spring Creek given our success in controlling nonnative brook trout in this once-important Eagle Lake rainbow trout habitat. Complementary measures may also be required. For example, construction of a two-way fish weir (Carbine and Shetter 1943; Whalls et al. 1955) at the lower end of Bogard Spring Creek could prevent or slow repopulation by brook trout (e.g., Phinney 1975; Peterson et al. 2004) yet would allow Eagle Lake rainbow trout to move upstream to spawn and juveniles to migrate downstream to Eagle Lake (Fausch et al. 2009). Periodic brook trout reduction programs will also be needed (Peterson et al. 2004); temporary eradication may even be possible if electrofishing is continued for at least 2-3 more years and if a barrier is constructed. Similar projects have allowed native populations of trout to rebound after nonnative trout abundance was decreased (e.g., Moore 
et al. 1983, 1986; Thompson and Rahel 1996); however, in some streams, invasive brook trout populations have not been successfully depressed by electrofishing and native trout have not rebounded (Meyer et al. 2006). Projects that have succeeded in eliminating nonnative trout from small streams have required 1-8 years of electrofishing removal with considerable effort (e.g., Kulp and Moore 2000; Shepard et al. 2002). Our study in Bogard Spring Creek shows that electrofishing can be an effective measure for controlling nonnative brook trout in small meadow streams, thus paving the way to native rainbow trout recovery.

\section{Acknowledgments}

The manuscript benefited from the helpful comments of journal editor Stephen Riley, Kevin Meyer, and an anonymous reviewer. The project was conducted by the Department of Wildlife, Fish and Conservation Biology at the University of California-Davis, with the collaboration of the U.S. Forest Service Lassen National Forest, Susanville Indian Rancheria, and CDFG. Funding was provided by the University of California Division of Agriculture and Natural Resources, National Fish and Wildlife Foundation, and Lassen County Resource Advisory Committee. Support for G.C.C. was provided by the University of California Water Resources Center, Trout Unlimited, American Fisheries Society Western Division (Eugene Maughan Scholarship), and Marin Rod and Gun Club; G.C.C. held a doctoral fellowship (BR2010/10) from the University of Girona during the final preparation of the manuscript. Funding for E.G.B. was received from the Spanish Ministry of Science (CGL2009-12877C02-01). Special thanks to Teresa Pustejovsky, Gabriel Green, Adam Clause, Karen Sorenson, Thomas Gildea, Kristofer Robison, David Lile, Kenneth Tate, James Hobbs, Calder Lee, Lisa Sedlack, Gerald Fujii, Joan Catot, Assumpta Carbonés, and numerous volunteers and technicians.

\section{References}

Benjamin, J. R., and C. V. Baxter. 2010. Do nonnative salmonines exhibit greater density and production than the natives they replace? A comparison of nonnative brook trout with native cutthroat trout. Transactions of the American Fisheries Society 139:641-651.

Bohlin, T., S. Hamrin, T. G. Heggberget, G. Rasmussen, and S. J. Saltveit. 1989. Electrofishing: theory and practice with special emphasis on salmonids. Hydrobiologia 173:9-43.

Carbine, W. F., and D. S. Shetter. 1943. Examples of the use of two-way fish weirs in Michigan. Transactions of the American Fisheries Society 73:70-89.

Carmona-Catot, G. 2009. Brook trout removal as a conserva- tion tool to restore Eagle Lake rainbow trout. Master's thesis. University of California, Davis.

Donald, D. B., and D. J. Alger. 1989. Evaluation of exploitation as a means of improving growth in a stunted population of brook trout. North American Journal of Fisheries Management 9:177-183.

Dunham, J. B., S. B. Adams, R. E. Schroeter, and D. C. Novinger. 2002. Alien invasions in aquatic ecosystems: toward an understanding of brook trout invasions and their potential impacts on inland cutthroat. Reviews in Fish Biology and Fisheries 12:373-391.

Fausch, K. D. 2008. A paradox of trout invasions in North America. Biological Invasions 10:685-701.

Fausch, K. D., B. E. Rieman, J. B. Dunham, M. K. Young, and D. P. Peterson. 2009. The invasion versus isolation dilemma: tradeoffs in managing native salmonids with barriers to upstream movement. Conservation Biology 23:859-870.

García-Berthou, E., and R. Moreno-Amich. 1993. Multivariate analysis of covariance in morphometric studies of the reproductive cycle. Canadian Journal of Fisheries and Aquatic Sciences 50:1394-1399.

Helfman, G. S. 2007. Fish conservation: a guide to understanding and restoring global aquatic biodiversity and fishery resources. Island Press, Washington, D.C.

Jelks, H. L., S. J. Walsh, N. M. Burkhead, S. ContrerasBalderas, E. Diaz-Pardo, D. A. Hendrickson, J. Lyons, N. E. Mandrak, F. McCormick, J. S. Nelson, S. P. Platania, B. A. Porter, C. B. Renaud, J. J. Schmitter-Soto, E. B. Taylor, and M. L. Warren Jr. 2008. Conservation status of imperiled North American freshwater and diadromous fishes. Fisheries 33:372-407.

Jenkins, T. M. Jr., S. Diehl, K. W. Kratz, and S. D. Cooper. 1999. Effects of population density on individual growth of brown trout in streams. Ecology (Washington, D.C.) 80:941-956.

Kulp, M. A., and S. E. Moore. 2000. Multiple electrofishing removals for eliminating rainbow trout in a small southern Appalachian stream. North American Journal of Fisheries Management 20:351-356.

Levin, P. S., S. Achord, B. Feist, and R. W. Zabel. 2002. Nonindigenous brook trout and the demise of threatened Snake River salmon: a forgotten threat? Proceedings of the Royal Society of London B 269:1663-70.

MacCrimmon, H. R., and J. C. Campbell. 1969. World distribution of brook trout, Salvelinus fontinalis. Journal of the Fisheries Research Board of Canada 26:16991725.

McFadden, J. T. 1961. A population study of the brook trout, Salvelinus fontinalis. Wildlife Monograph 7.

McFadden, J. T., G. R. Alexander, and D. S. Shetter. 1967. Numerical changes and population regulation in brook trout Salvelinus fontinalis. Journal of the Fisheries Research Board of Canada 24:1425-1459.

Meyer, K. A., J. A. Lamansky Jr., and D. J. Schill. 2006. An unsuccessful brook trout electrofishing removal project in a small Rocky Mountain stream. North American Journal of Fisheries Management 26:849-860.

Moore, S. E., B. Ridley, and G. L. Larson. 1983. Standing crops of brook trout concurrent with removal of rainbow trout from selected streams in Great Smoky Mountains 
National Park. North American Journal of Fisheries Management 3:72-80.

Moore, S. E., G. L. Larson, and B. Ridley. 1986. Population control of exotic rainbow trout in streams of a natural area park. Environmental Management 10:215-219.

Moyle, P. B. 2002. Inland fishes of California. University of California Press, Berkeley.

Moyle, P. B., and G. Carmona-Catot. 2009. Restoration of wild Eagle Lake rainbow trout: management recommendations. Report to the National Fish and Wildlife Foundation, Washington, D.C., and Lassen County Resource Advisory Council, Susanville, California.

Moyle, P. B., J. A. Israel, and S. E. Purdy. 2008. Salmon, steelhead, and trout in California: status of an emblematic fauna. University of California, Davis. Available: www. caltrout.org/SOS-Californias-Native-Fish-Crisis-FinalReport.pdf. (April 2010).

Peterson, D. P., and K. D. Fausch. 2003. Dispersal of brook trout promotes invasion success and replacement of native cutthroat trout. Canadian Journal of Fisheries and Aquatic Sciences 60:1502-1516.

Peterson, D. P., K. D. Fausch, and G. C. White. 2004. Population ecology of an invasion: effects of brook trout on native cutthroat trout. Ecological Applications 14:754-772.

Peterson, N. P., and C. J. Cederholm. 1984. A comparison of the removal and mark-recapture methods of salmon in a small stream. North American Journal of Fisheries Management 4:99-102.

Phinney, D. E. 1975. Repopulation of an eradicated stream section by brook trout. Transactions of the American Fisheries Society 104:685-687.

Pustejovsky, T. 2007. A conservation plan for Pine Creek and Eagle Lake rainbow trout. Lassen County Resource Advisory Council, Susanville, California.
Rieman, B. E., J. T. Peterson, and D. L. Myers. 2006. Have brook trout displaced bull trout along longitudinal gradients in central Idaho streams? Canadian Journal of Fisheries and Aquatic Sciences 63:63-78.

Riley, S. C., and K. D. Fausch. 1992. Underestimation of trout population size by maximum-likelihood removal estimates in small streams. North American Journal of Fisheries Management 12:768-776.

Roghair, C. N., and C. A. Dolloff. 2005. Brook trout movement during and after recolonization of a naturally defaunated stream reach. North American Journal of Fisheries Management 22:777-784.

Shepard, B. B., R. Spoon, and L. Nelson. 2002. A native westslope cutthroat trout population responds positively after brook trout removal and habitat restoration. Intermountain Journal of Sciences 8:193-214.

Strange, R. J. 1996. Field examination of fishes. Pages 433 446 in B. R. Murphy and D. W. Willis, editors. Fisheries techniques, 2nd edition. American Fisheries Society, Bethesda, Maryland.

Thompson, P. D., and F. J. Rahel. 1996. Evaluation of depletion-removal electrofishing of brook trout in small Rocky Mountain streams. North American Journal of Fisheries Management 16:332-339.

Van Deventer, J., and W. S. Platts. 1989. Microcomputer software system for generating population statistics from electrofishing data-user's guide for MicroFish 3.0. U.S. Forest Service General Technical Report INT-254.

Whalls, M. J., K. E. Proshek, and D. S. Shetter. 1955. A new two-way fish trap for streams. Progressive Fish-Culturist 17:103-9.

Young, S. L. 1989. Pine Creek watershed report. U.S. Forest Service, Lassen National Forest, Eagle Lake Ranger District, Susanville, California. 